\title{
浅い干潟面上で岸向きに発達する細長い砂州の 形成予測-BGモデルの応用 \\ MODEL FOR PREDICTING FORMATION OF SLENDER SAND BAR DUE TO SHOREWARD SAND TRANSPORT ON SHALLOW TIDAL FLATS
}

\author{
芹沢真澄1 ・宇多高明 2 ・宮原志帆 3 \\ Masumi SERIZAWA, Takaaki UDA and Shiho MIYAHARA \\ 1正会員 海岸研究室（有）（广160-0011 東京都新宿区若葉1-22 ローヤル若葉301） \\ 2 正会員 工博 (財) 土木研究センター常務理事なぎさ総合研究室長兼日本大学客員教授 \\ 理工学部海洋建築工学科（テ110-0016 東京都台東区台東1-6-4タカラビル） \\ 3海岸研究室（有）（厂160-0011 東京都新宿区若葉1-22 ローヤル若葉301）
}

\begin{abstract}
Shoreward transport of sand originally supplied from the offshore zone of the tidal flats, while forming a slender sand bar, and the landing of such sand were observed on the Kutsuo coast, where very wide tidal flats develop. Although this landward sand movement due to waves on the shallow tidal flats is part of the returning process of sand transported offshore by river currents during floods, its mechanism has not yet been studied. We investigated this phenomenon by considering the Kutsuo coast as an example. Then, we performed numerical simulation using the BG model to predict such shoreward sand movement. The observed phenomena were successfully explained by the results of the numerical simulation.
\end{abstract}

Key Words : Tidal flats, sand bar, formative mechanism, BG model, numerical simulation

\section{1. まえがき}

ある程度の波高を持った波の作用のある内湾干潟 では, 干潟縁辺部に砂浜が発達し, 平坦な干潟面と 勾配 $1 / 10$ 程度の砂浜とが遷急線を境にきれいに分か れる状況がしばしば観察される。例えば，中津干潟 の三百間砂州 ${ }^{1)}$ がその典型例である。このような干 潟縁辺部の砂浜でも, 外海・外洋に面した海岸と同 様，斜め入射波による沿岸漂砂や，高潮時における 砂州越流に伴う岸向きの砂移動が起こる. しかしな がらこれらとは全く別に，干潟と砂浜との interactionとして, 洪水流などによって沖向きに運 ばれ干潟上に堆積した砂が, 細長い砂州を形成しつ つ陸岸に戻る現象もしばしば観察される。中津干潟 の三百間砂州では, その東端部に本体砂州の汀線と ほぼ直交するひげ状砂州が常に発達している。この ように浅い平坦面の続く干潟面上における砂移動は, 沖合の干潟面へと運ばれた砂が波の作用により岸向 きに運ばれる現象を表すと考えられるが，その発生 機構の解明は行われたことがない。そこで, 本研究 では中津干潟と同様，周防灘に面寸る沓尾海岸を対 象として, この種の現象について現地調査を行うと ともに，芹沢ら ${ }^{2}$ のBGモデル（Bagnold概念に基づく 海浜変形モデル）を応用してその機構解明を進めた。

\section{2. 空中写真と深浅図による細長い砂州の確認}

図-1は1999年撮影の沓尾海岸の空中写真を示す. 祓川河口左岸には砂州が伸びているが，同時に祓川 河口から沖合の干潟へと続く澪筋の北側側面に沿っ て河口砂州の汀線とほぼ直交する細長い砂州の発達 が認められる.この細長い砂州の西端は河口砂州と つながっている. 砂の供給源は祐川と見られ, 洪水

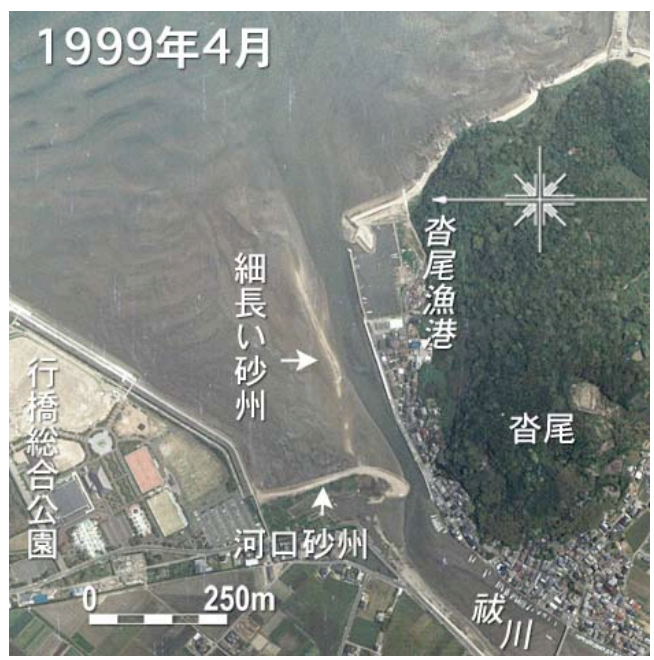

図-1 沓尾海岸の空中写真（1999 年） 


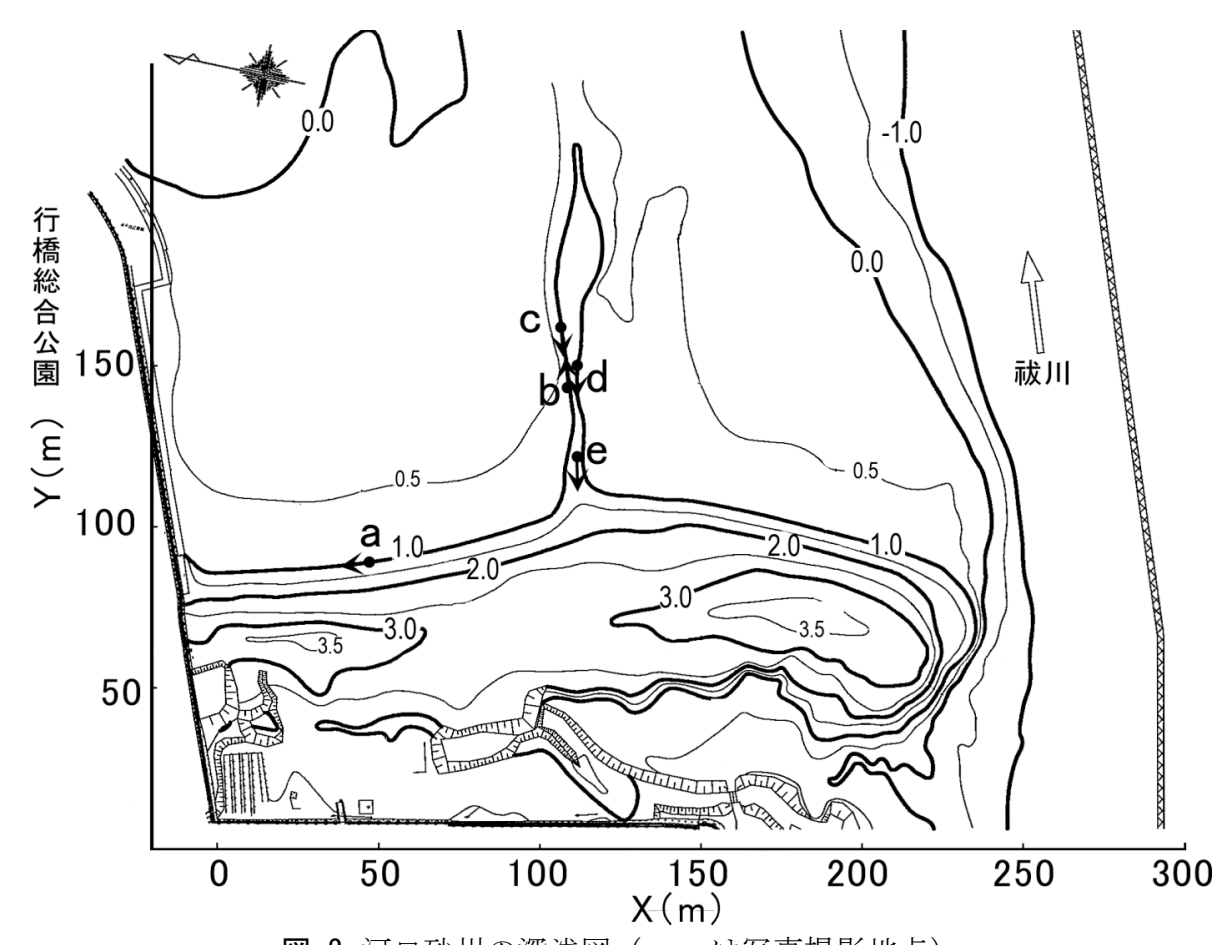

図-2 河口砂州の深浅図（a〜e は写真撮影地点）

時に沖向きに運ばれた砂が澪筋の北側近傍に堆積し， それが波の作用で移動していると推測される。

一方，この区域では図-1に示す細長い砂州は常時 発達している。図-2は2008年の測量結果（基準面 D. L. =T. P. -0.1m）を示すが，細長い砂州の成長して いる場所が図-1と比べ北側へずれているものの，ほ ぼ中央部の $\mathrm{X}=120 \mathrm{~m}$ 付近では縦方向に細長い砂州が伸 び，そこで汀線が突出している。なお，この海岸の HWLはT.P.+2.07mにあるので，満潮時における平坦 面の水深は約 $2 \mathrm{~m}$ とる. 砂州沖と海浜との関係を調 べると，前浜は $1.0 \mathrm{~m}$ から $3.0 \mathrm{~m}$ の間で発達している. この間には中砂または粗砂が堆積し, 前浜勾配は 1/10と急である。一方，標高 $1.0 \mathrm{~m} よ り$ 沖合には干潟 の平坦面が発達している。また縦方向に伸びた砂州 の南北で平坦面の標高に違いがあり, 祐川河口に近 接する南側で地盤高が高い。

\section{3. 沓尾海岸での細長い砂州に関する現地調査}

2009年 12 月 27 日早朝の干潮時, 沓尾海岸の砂州の 現地踏査を行った。沓尾海岸の北端は図-3のように 行橋総合公園前面の直立堤防により区切られている. 海浜は粘着性の大きな潟土で覆われた干潟面から急 勾配で立ち上がり，砂浜と干潟面とは明瞭な遷急線 で区分される。薄く水が溜まった干潟には一歩足を 踏み入れると足が取られるほど粘着性が高いのに対 し，左側の砂浜は固く締まっていた。図-4は細長い 砂州の全体状況を示す. 細長い砂州は満潮時には水 没するが，干潮時には写真のように干潟面上に姿を 現す。細長く長大な砂州が平均海岸線と直交方向に 伸びている。砂州両側の地盤高を比較すると, 右

（南）側の地盤高が左（北）側の地盤高より高く,
北側では潟土で覆われているのに対し，南側では表 面に砂の堆積もあって地盤高が高い。この砂州の南 側には祐川が流入し, そこから干潟面へと運ばれた 砂が漂砂により岸向きに運ばれ堆積するが，北側区 域ではそのような漂砂が砂州によって断たれている

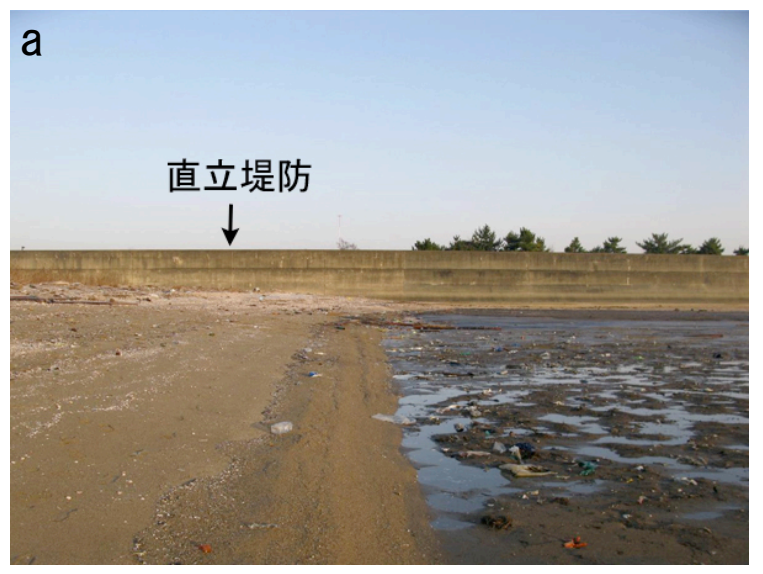

図-3 行橋総合公園前面の直立堤防

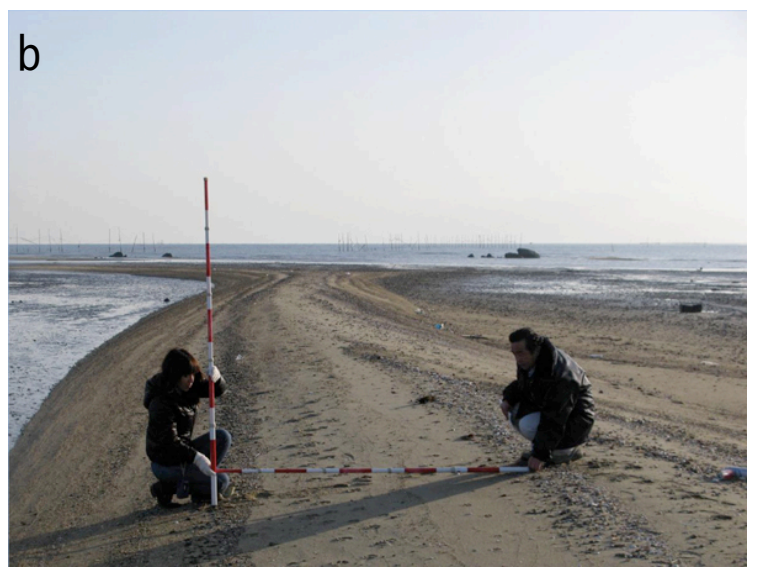

図-4 細長い砂州の全体状況 


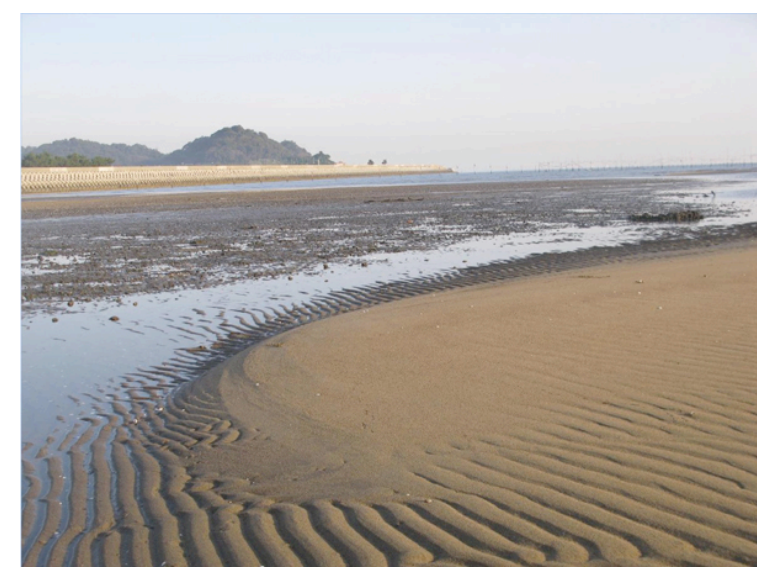

図-5 小規模な砂州の先端状況

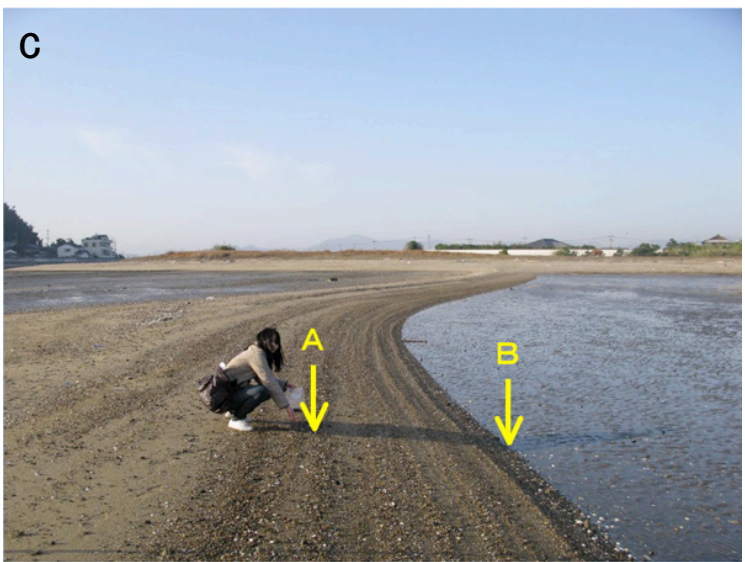

図-6 細長い砂州の先端部付近から陸を望んで撮影

ことが地盤高の相違の原因と考えられる．図-5は， 図-4に示寸細長い砂州の先端部から枝分かれした小 規模な砂州の先端状況を示寸。この砂州上では，河 川によって沖合へと運ばれたと見られる風化花崗岩 砂（マサ土）が集積し，砂州は陸向きに次第に標高 が高まるが，陸側端では急傾斜で干潟面へと落ち込 む勾配を有していた.

図-6は，細長い砂州の先端部付近から陸を望んで 撮影したものである. 砂州の北側面では前浜勾配 1/10で砂礫が堆積していたが，B点では前浜と干潟 面がきれいに分かれていた，A点での底質のフルイ 分け分析によれば $d_{50}=1.50 \mathrm{~mm}$ であった。

図-7は陸岸に近い場所から砂州の付け根方向を望 んだものである. 砂州は陸岸近傍でくびれを有して いる. また砂州には満潮時の波の痕跡線が直線状に 伸びている. 図-8は, 細長い砂州と陸との接点付近 の状況を示す。三角形状の縞模様は, 各潮位条件で の細長い砂州の汀線とほぼ直角方向から波が作用し たため残されたと考えられる. 汀線への入射角が著 しく大きくなれば沿岸漂砂も増大し, この細長い砂 州は消失しなければならないことを考えれば，細長 い砂州の発達によって汀線への入射角および波高が 低減する機構が存在すると見られる. 砂州の構成材 料は潟土とは大きく異なり, 粗砂または中砂であっ た. 砂の連続性とこの細長い砂州が常時発達してい る点を考えれば, 砂州を構成する砂は祓川から洪水 時に干潟に運ばれたものと考えられる。一連の観察

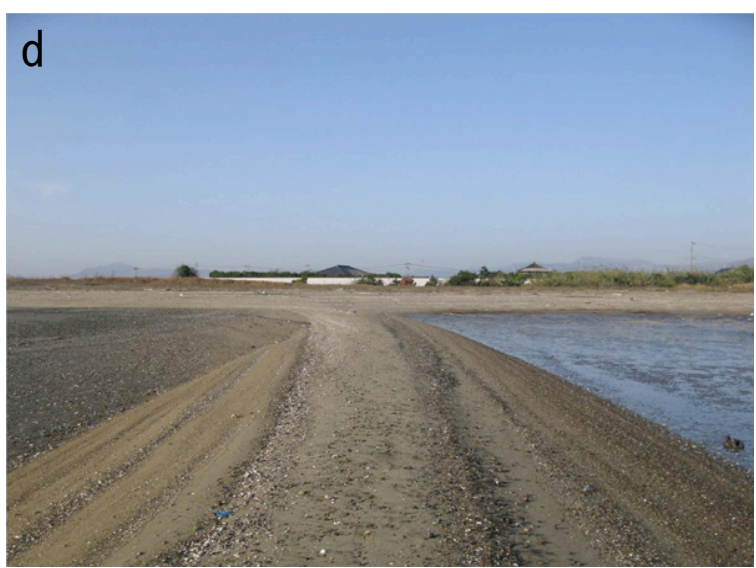

図-7 くびれた細長い砂州の状況

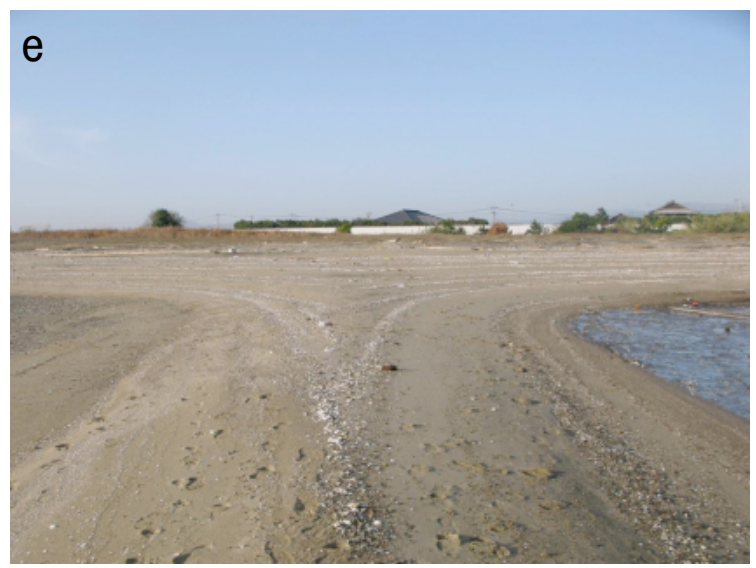

図-8 細長い砂州と陸との接点付近の状況

結果は，沖合の干潟面へと運ばれた砂が，波による 岸向き漂砂によって運ばれつつある状態に対応して いると見られる. 外海・外洋に面した海岸では, 海 岸線と直交方向に砂州が安定的に伸びることは困難 であり, 波の作用で直ちに潰れることを考えれば, 干潟という平坦面上での波の作用によって特有な現 象が生じたと考えられる.

\section{4. 予測モデル}

芹沢ほか22)のBGモデルをもとに地形変化予測を 行った，計算の基本式には，砕波波高の沿岸方向勾 配に起因する沿岸漂砂量を考慮するためのOzasa and Brampton項 ${ }^{3)}$ を付加した式（1）を用いた.

$$
\begin{aligned}
& \vec{q}=C_{0} \frac{P}{\tan \beta_{\mathrm{c}}}\left\{\begin{array}{l}
K_{n}\left(\tan \beta_{c} \vec{e}_{w}-|\cos \alpha| \overrightarrow{\nabla Z}\right) \\
\left\{\left(K_{s}-K_{n}\right) \sin \alpha-\frac{K_{2}}{\tan \beta} \frac{\partial H}{\partial s}\right\} \tan \beta \overrightarrow{e_{s}}
\end{array}\right\} \\
& \left(-h_{c} \leq Z \leq h_{R}\right) \\
& P=\rho u_{m}^{3} \\
& u_{m}=\frac{H}{2} \sqrt{\frac{g}{h}}
\end{aligned}
$$


ここに, $\vec{q}=\left(q_{x}, q_{y}\right)$ はネットの砂輸送フラックス, $Z(x, y, t)$ は地盤高， $n$ および $s$ 等深線直角方向（岸 向き) および平行方向に取った局所座標， $\overrightarrow{\nabla Z}=(\partial Z / \partial x, \partial Z / \partial y)$ は地形の勾配ベクトル， $\overrightarrow{e_{w}}$ は波 向の単位ベクトル， $\vec{e}_{s}$ は等深線平行方向の単位ベク トル， $\alpha$ は波向之等深線直角方向のなす角, $\tan \beta=|\overrightarrow{\nabla Z}|$ は海底勾配, $\tan \beta_{c}$ は平衡勾配, $\tan \beta \vec{e}_{s}=(-\partial Z / \partial y, \partial Z / \partial x), K_{s}, K_{n}$ はそれぞれ沿岸・ 岸沖漂砂量係数, $K_{2}$ はOzasa and Brampton項の係数, $\partial H / \partial s=\overrightarrow{e_{s}} \cdot \overrightarrow{\nabla H}$ は等深線平行方向に測った波高Hの勾 配, $\tan \beta$ は砕波带の代表海底勾配である。また $C_{0}$ は水中重量表示から体積表示への換算係数 $\left(C_{0}=1 /\left\{\left(\rho_{s}-\rho\right) g(1-p)\right\} ; \rho\right.$ は海水の比重, $\rho_{\mathrm{s}}$ は砂の 比重, $p$ は砂の空隙率, $g$ は重力加速度）, $u_{m}$ は波の 底面振動流速 $\left(u_{m}=H / 2 \sqrt{g / h}, H\right.$ は波高, $h$ は水 深）, $h_{c}$ は波による地形変化の限界水深， $h_{R}$ は バーム高である.

波浪場の計算には，不規則波の方向スペクトルを 変数とする間瀬ら ${ }^{4)}$ によるエネルギー平衡方程式の 数值計算法を用い, 挽波減衰項にはDally $ら^{5)}$ 用い た。 また波の打ち上げ領域での波浪場の計算には, 芹沢 $5^{2)}$ と同様仮想水深を設定し, 仮想水深 $h$ 'を式 (4)で与えた.

$$
h^{\prime}=\left(\frac{h_{R}-Z}{h_{R}+h_{0}}\right)^{\mathrm{r}} h_{0} \quad(\mathrm{r}=1) \quad\left(-h_{0} \leq Z \leq h_{R}\right)
$$

入射波は事例として選択した沓尾海岸における年間 のエネルギー平均波とし，入射波高を $H_{i}=0.4 \mathrm{~m}$, $T=3 \mathrm{~s}$ とした. また波向は初期汀線に対して直角方向 からの入射, 潮位条件は沓尾海岸でのH. W. L. $=+2 \mathrm{~m}$ と した. この場合干潟の平坦面の水深は $2 \mathrm{~m}$ となる. 干 潟の平坦面は固定床として扱い, 固定床上の岸端に は前浜勾配 $1 / 10$ の海浜を設定した。 バーム高は $0.5 \mathrm{~m}$, 波による地形変化の限界水深は任意点の波高を $H$ と して $h_{c}=2.5 H$ で与えた. 砂の平衡勾配は $1 / 10$, 安息 勾配は $1 / 2$ とした。計算領域は $\Delta x=\Delta y=5 \mathrm{~m}$ で分割し, 計算時間間隔は $\Delta t=0.1 \mathrm{hr}$ とした. 総計算ステップ数 は $5 \times 10^{4}$ ステップ (5000時間) である.

本研究では, 地形変化に応じた波浪場変化の フィードバック計算を多数回繰り返すために, 計算 負荷が大きくならないようエネルギー平衡方程式法 を用いて波浪場を算出し, 波浪場は地形変化計算 10 ステップごとに計算し直した。潟面上において岸 向き漂砂によって砂が集積し, それが細長い砂州を 形成する現象のモデル化のために, 本研究では 1 メッシュ $(5 \mathrm{~m} \times 5 \mathrm{~m})$ の点源で砂の湧き出しを与えた. 図-2によれば, 細長い砂州は汀線沖 $120 \mathrm{~m}$ 付近から発 達しているが，計算ではやや沖の $170 \mathrm{~m}$ 沖に湧き出し 点を設けた。 その量はtrail and errorの方法で設定し た. 最終的に土砂湧き出しは $(x, y)=(200 \mathrm{~m}, 0 \mathrm{~m})$ 地 点において $3.75 \times 10^{4} \mathrm{~m}^{3} / \mathrm{yr}$ とした。詳細な計算条件 を表-1に示す. さらに, 島の高さについては $0.5 \mathrm{~m} の$
表-1 計算条件

\begin{tabular}{|c|c|}
\hline 波浪条件 & $\begin{array}{l}\text { 入射波: } H_{I}=0.4 \mathrm{~m}, \quad T=3 \mathrm{~s} \\
\text { 波向 : 初期汀線に対して } q_{I}=0^{\circ}\end{array}$ \\
\hline 潮位条件 & H.W.L. $=+2.0 \mathrm{~m}$ \\
\hline バーム高 & $h_{R}=0.5 \mathrm{~m}$ \\
\hline $\begin{array}{l}\text { 波による地形変 } \\
\text { 化の限界水深 }\end{array}$ & $h_{c}=2.5 H$ (Hは波高 $)$ \\
\hline 平衡勾配 & $\tan \beta_{c}=1 / 10$ \\
\hline 安息勾配 & $\tan \beta_{g}=1 / 2$ \\
\hline 漂砂量係数 & $\begin{array}{l}\text { 浻岸漂砂量係数 } K_{s}=0.05 \\
\text { 小笹 } \cdot \text { Brampton 項 } の \text { 漂 砂 量 係 数 } \\
K_{2}=1.62 K_{s} \\
\text { 岸沖漂砂量係数 } K_{n}=0.2 K_{s}\end{array}$ \\
\hline 計算メッシュ & $\Delta x=\Delta y=5 \mathrm{~m}$ \\
\hline 計算時間間隔 & $\Delta t=0.1 \mathrm{hr}$ \\
\hline 計算ステップ数 & $5 \times 10^{4}$ steps $(5000 \mathrm{hrs})$ \\
\hline 境界条件 & 岸沖端 : $q_{x}=0$, 左右端 : $q_{y}=0$ \\
\hline 波浪場の計算法 & 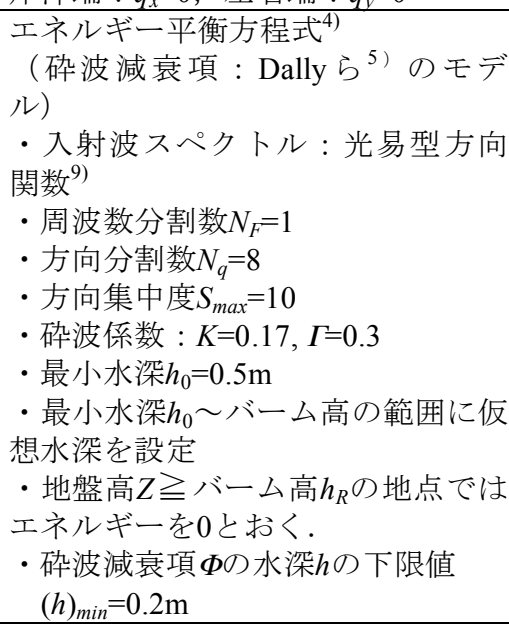 \\
\hline 備考 & $\begin{array}{l}\text { 1メッシュからの点源土砂湧き出 } \\
\text { し: } 3.75 \times 10^{4} \mathrm{~m}^{3} / \mathrm{yr}\end{array}$ \\
\hline
\end{tabular}

上限值を設けた。計算の過程で地形変化によって地 盤高がこの值に到達した地点では波エネルギーを0 と置いた。

\section{5. 計算結果}

\section{(1) 平面形状の変化}

図-9には $(x, y)=(200 \mathrm{~m}, 0 \mathrm{~m})$ 地点において砂の湧 き出しを与えた場合の計算結果を示寸。計算は初期 から $5 \times 10^{4}$ ステップまで行っているが，等深線の変 化を初期から $10^{4}$ ステップごとに表示している。初 期には砂の湧き出しがないので平坦面が広がるのみ である. 図の黒丸が砂の湧き出し点である.また干 潟が陸地と接する場所には沓尾海岸で観察されたよ うに, $1 / 10$ 勾配の砂浜を設定している. この状態で 波が作用寸ると，104ステップまでに湧き出した砂 が堆積し細長い島が形成される. 島の陸側端は鋭く 尖り, comet tail状となる. また対岸では形成された 島が波の遮蔽効果を発揮するために周辺海岸から島 背後へ向から沿岸漂砂が誘起され, 舌状砂州の形成 が始まる． $2 \times 10^{4}$ ステップには，島の発達が続き対 岸に接続する. またこの時までに島背後の舌状砂州 は $10^{4}$ ステップと比べるとさらに発達を遂げる。ま 
(a) 0 step

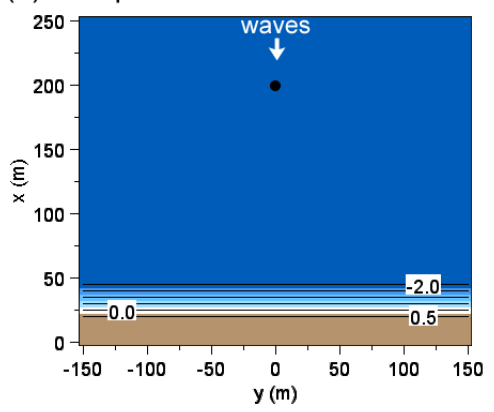

(d) $3 \times 10^{4}$ steps

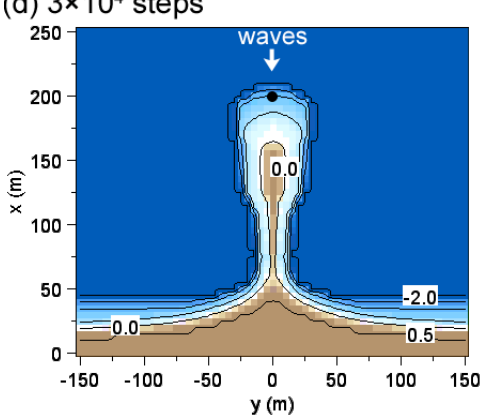

(b) $1 \times 10^{4}$ steps

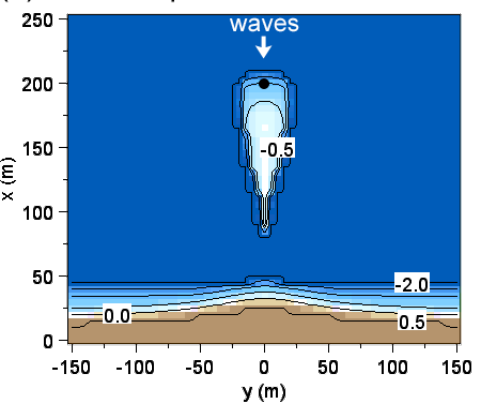

(e) $4 \times 10^{4}$ steps

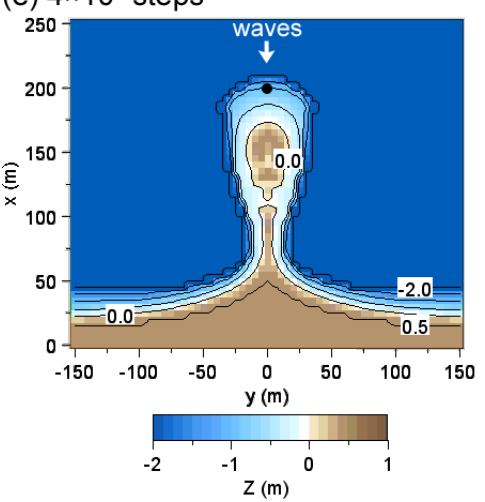

(c) $2 \times 10^{4}$ steps

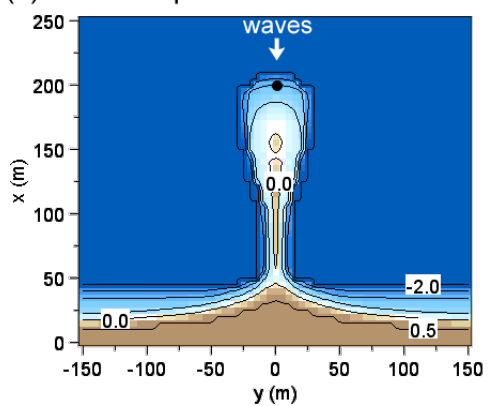

(f) $5 \times 10^{4}$ steps

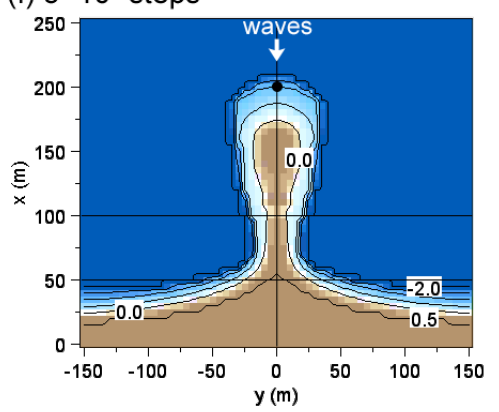

図-9 計算結果

た砂の湧き出し点と陸との間の $X=50 \sim 100 \mathrm{~m}$ 区間での 砂州幅は狭く, くびれを有する地形となる． $3 \times 10^{4}$ ステップでは，島および島背後のくびれ部分の幅が 増加するとともに, 湧き出した砂が陸に到達し島の スプーン状に突出した汀線と背後のトンボロの汀線 が繋がる. 砂州の発達は $4 \times 10^{4}, 5 \times 10^{4}$ ステップと 続き, 砂の湧き出し点付近と島とトンボロの間の砂 州のくびれ部分とも砂州幅が増大寸る。一連の砂州 の発達は, 図-2の測量結果や, 図-6,7,8に示した細 長い砂州が陸地近傍でくびれを有する点など実測結 果をうまく説明している.

\section{(2) 砂州の縱断・横断形の変化}

図-9(f)に示したように，砂州の中心を通る $y=0 \mathrm{~m}$ で砂州を切断した場合の縦断形変化を図-10に示す. 砂州の縦断形変化では砂州の成長が急速なため $10^{4}$ ステップでは地形変化を的確に表せないことから， $5 \times 10^{3}$ と $1.5 \times 10^{4}$ ステップの計算結果も示す. 砂州 は岸向きに伸びていくが, 砂州背後では砂州自体に よる波の遮蔽効果により波高が低下寸るため限界水 深も小さくなり，例えば $1 \times 10^{4}$ ステップでは $Z=-$ $0.5 \mathrm{~m}$ 以深で $1 / 2$ の安息勾配を持った急斜面が形成さ れる. しかし砂州が陸岸に到達すると, 陸と砂州の 間の地盤も高まり, 最終的に砂州高は既知量として 設定したバーム高 $h_{R}=0.5 \mathrm{~m}$ へと収束する.

図-11は図-9(f) に示すように，砂州のくびれを横 断する $X=100 \mathrm{~m}$ と初期状態での砂浜と干潟との境界付 近の $x=50 \mathrm{~m}$ 横断する測線における砂州の横断形の 変化を示す． $X=100 \mathrm{~m}$ では $1 \times 10^{4}$ ステップまでに両側 面が安息勾配で落ち込む尖った砂州が形成され，そ の後時間が経過しても砂州幅はあまり広がらない。 一方, $x=50 \mathrm{~m}$ 断面では, $x=100 \mathrm{~m}$ 断面と比べて島が成

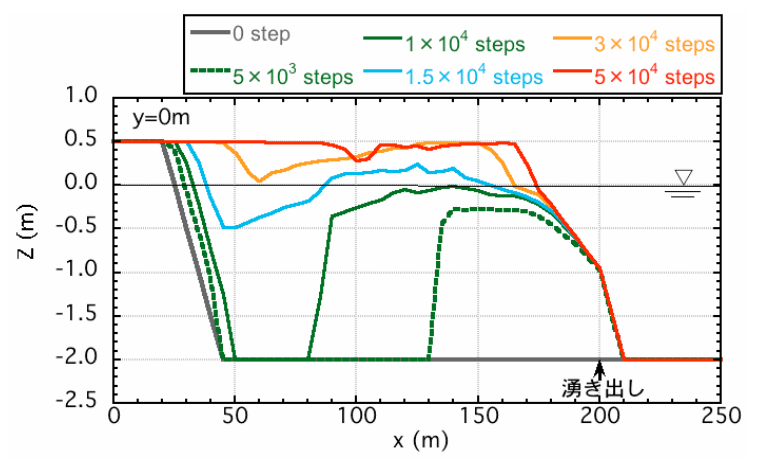

図-10 縦断形変化
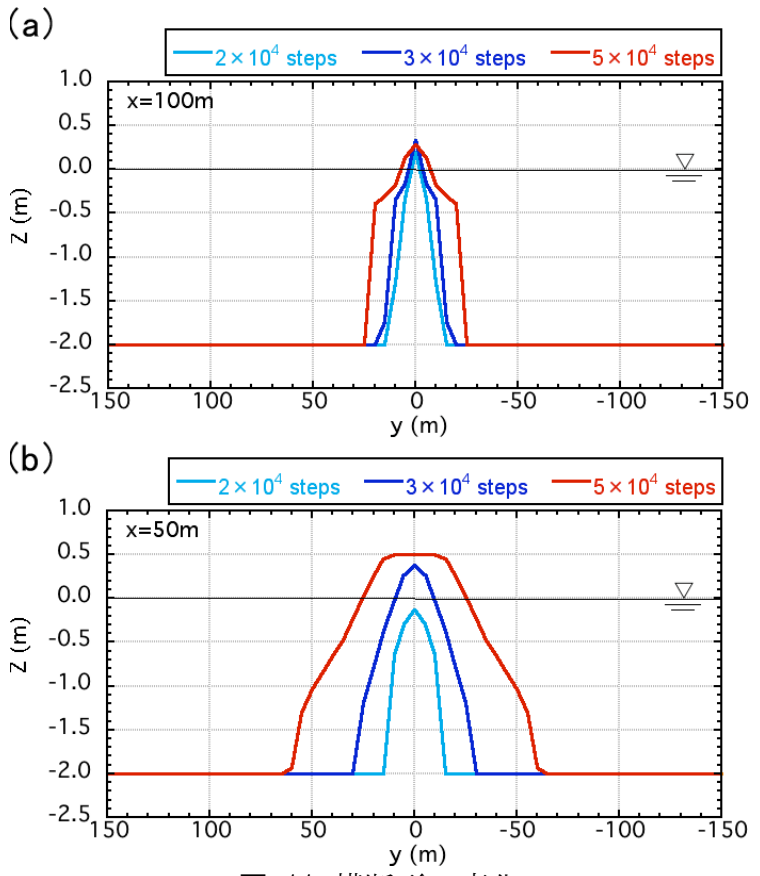

図-11 横断形の変化 
(a) 0 step

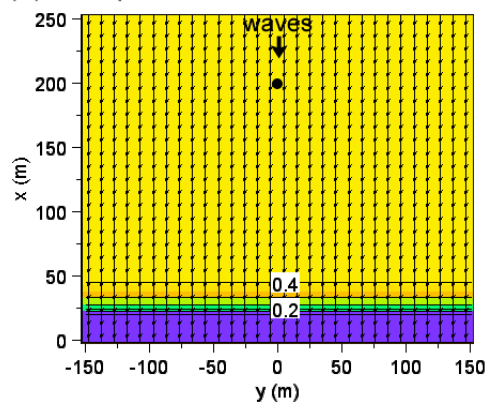

(d) $3 \times 10^{4}$ steps

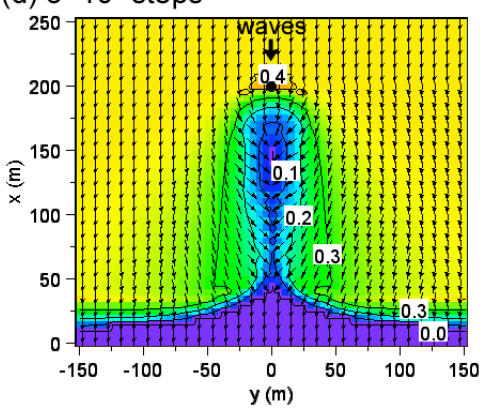

(b) $1 \times 10^{4}$ steps

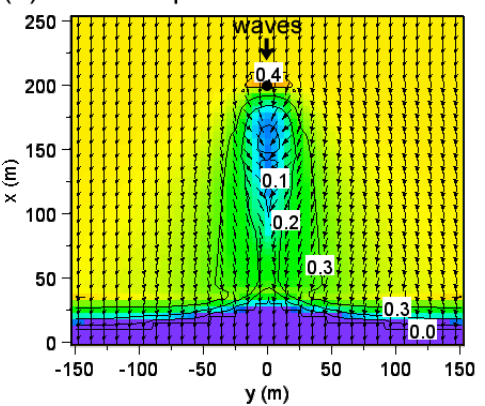

(e) $4 \times 10^{4}$ steps

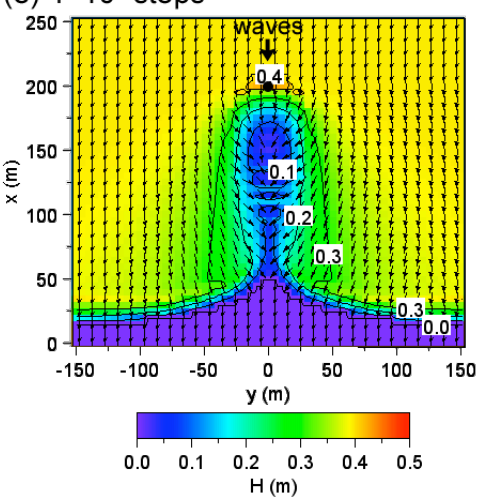

(c) $2 \times 10^{4}$ steps

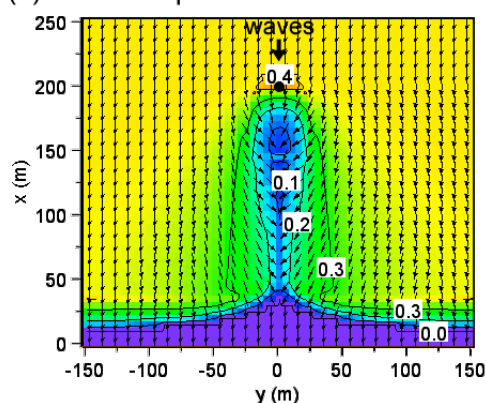

(f) $5 \times 10^{4}$ steps

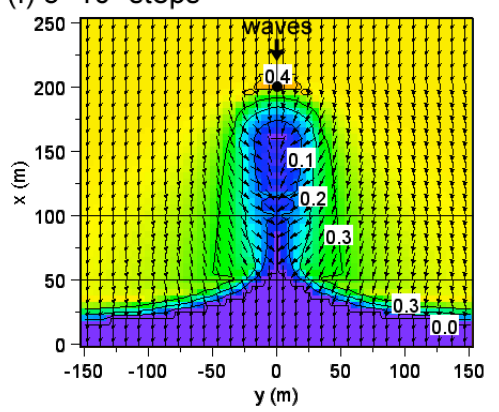

図-12 波浪場の変化

長するに従い波の遮蔽効果が上昇するため舌状砂州 の発達も助長され，幅が増大している。

\section{（3）波浪場の変化}

地形変化と対応する波浪場の変化を図-12に示す. 0ステップでは干潟面上の波高は一定で，陸と干潟 の間にある砂浜で一様な砕波減衰が起こる. $1 \times 10^{4}$ ステップでは砂の湧き出しにより形成された浅瀬が 波浪場に変化をもたらし，砂州の陸側の区域での波 高低下と同時に，回折効果により島の両側での波が 斜め入射となる。このような斜め入射波は砂州の等 深線に沿う岸向きのフラックスを生じさせる。一方, 島陰では離岸堤の背後と同様な形式で波高低下が起 こり，これは島背後の中心へと向いた沿岸漂砂を誘 起することとなる. $2 \times 10^{4}$ ステップでは砂州が陸へ 向かって細長く伸びて水深が小さくなった結果そこ で砕波が起こり，著しい波高低下が起こる．同時に この部分では斜め入射の状態が続くので，島から陸 岸への漂砂が続く. $4 \times 10^{4}, 5 \times 10^{4}$ ステップにおい ても幅が広がった砂州周辺においてほぼ同じ状況が 続く.

\section{6. まとめ}

浅い平坦面の続く干潟面上において汀線とほぼ直 角方向に伸びる細長い砂州の発達を周防灘に面する 沓尾海岸を対象として現地データを基に調べた。 そ の上で芹沢ら ${ }^{2)}$ のBGモデルを応用してその機構解明 を進めた. モデルでは沖合の海底面に砂の湧き出し を与えることにより表現した. この結果, 海岸線と
ほぼ直角方向に伸びる細長い砂州の発達現象を数值 モデルによりほぼ再現できることが分かった，従来， $\mathrm{BG}$ モデルは河口砂州の発達予測 ${ }^{6)}$, 単純砂嘴の発達 予測 ${ }^{72}{ }^{2)}$ や, bay barrier の発達予測 ${ }^{8)}$ に有効利用で きることが明らかにされているが，本研究により BG モデルの適用範囲をさらに拡げることができた.

\section{参考文献}

1) 宇多高明, 清野聡子, 足利由紀子, 城野博之：高潮に 伴う中津干潟三百間地区の砂州の急変形, 海岸工学論 文集，第 55 巻，pp. 481-485， 2008.

2) 芹沢真澄, 宇多高明, 三波俊郎, 宮原志帆: 海岸線が 急変する場での砂嘴の発達予測, 地形, Vol. 31, pp. 403-422, 2010.

3) Ozasa, H. and Brampton, A. H.: Model for predicting the shoreline evolution of beaches backed by seawalls, Coastal Eng., 4, pp. 47-64, 1980.

4) 間瀬 肇，高山知司，国富将嗣，三島豊秋: 波の回折を 考慮した多方向不規則波の変形計算モデルに関する研 究，土木学会論文集，628/II 48，pp. 177-187， 1999.

5) Dally, W. R., Dean, R. G. and Dalrymple, R. A.: A model for breaker decay on beaches, Proc. 19th ICCE, pp. 82-97, 1984.

6) 芹沢真澄, 宇多高明, 三波俊郎, 古池 鋼, 石川仁 憲: 河口砂州復元の 3 次元予測モデル, 海洋開発論文 集，第 25 巻，pp. 1155-1160， 2009.

7) Serizawa, M., Uda, T., San-nami, T., Furuike, K. and Ishikawa, T.: Prediction of topographic changes of sand spit using BG model, J. Coastal Res., SI56, pp. 1060-1064, 2009.

8) 芹沢真澄, 宇多高明：浅海平坦面上に発達する Bay barrier の形成予測モデル, 地形, Vo1.31, pp. 33-54, 2010.

9) 合田良實：港湾構造物の耐破設計：鹿島出版会, p. 303, 1990. 